\title{
REVIEW
}

\section{Agroforestry for Climate Change Adaptation, Resilience Enhancement and Vulnerability Attenuation in Smallholder Farming Systems in Cameroon}

\author{
Nyong Princely Awazi* \\ Department of Forestry and Wildlife Technology, College of Technology, The University of Bamenda, Cameroon
}

ARTICLE INFO

Article history

Received: 31 December 2021

Accepted: 20 January 2022

Published : 27 January 2022

\section{Keywords:}

Climate change

Agroforestry

Smallholder farmers

Smallholder farming systems

Vulnerability

Adaptation

Resilience

Cameroon

\begin{abstract}
The adverse impacts of climate variability and change are felt mostly by smallholder farmers and smallholder farming systems where rainfed agriculture is predominant. Continuous dependence on rain-fed agriculture has led to declining crop productivity and crop failure in most cases as weather patterns shift which is very problematic for crop growth. Agroforestry which is one of the climate-smart, environmentally benign and agroecological practices has been found to mitigate climate change adversities while fostering adaptation, enhancing resilience and attenuating vulnerability especially in smallholder farming systems. However, in Cameroon, limited empirical research has been done to ascertain the role played by agroforestry in climate change adaptation, resilience enhancement and vulnerability attenuation. This paper which is based on an in-depth review of literature was undertaken to uncover what has been done so far in terms of empirical studies tackling the role played by agroforestry in climate change adaptation, resilience and vulnerability attenuation in Cameroon. It was found that most of the empirical studies have been carried out in one agroecological zone - the western highlands of Cameroon, showing that smallholder farmers adopt different agroforestry practices in the face of climate change with the most common being home gardens with livestock, home gardens without livestock, scattered trees on croplands, improved fallows, live fences/hedges and windbreaks, coffeebased agroforestry, cocoa-based agroforestry, apiculture-based agroforestry, fodder banks, and plantation crop-based agroforestry practices. These agroforestry practices provide a plethora of ecosystem services categorized into provisioning, supporting, regulating and cultural which play an important role towards fostering climate change adaptation, enhancing resilience and attenuating vulnerability in smallholder farming systems. From the findings uncovered by this study, it is imperative for more empirical studies to be carried out in the other four agroecological zones of Cameroon where there is a paucity of information regarding the role played by agroforestry towards fostering climate change adaptation, enhancing resilience and attenuating vulnerability in smallholder farming systems.
\end{abstract}

*Corresponding Author:

Nyong Princely Awazi,

Department of Forestry and Wildlife Technology, College of Technology, The University of Bamenda, Cameroon;

Email: awazinyong@uniba.cm; nyongprincely@gmail.com 


\section{Introduction}

Smallholder farming systems are the most dominant farming systems in the developing world and they contribute towards feeding over half of the population in developing countries ${ }^{[1]}$. These farming systems which are often less than 2 hectares are used for the cultivation of crops like maize, beans, millet, sorghum, coffee, tea, cocoa, oil palms, plantains, banana which supply the nutrient needs of the population ${ }^{[2]}$. However, smallholder farming systems are today severely threatened by changing weather patterns and recurrent extreme weather events induced by global warming and climate change ${ }^{[3]}$. The adverse impacts of climate change on smallholder farming systems are having ripple effects on smallholder farmers as crop productivity decline and crop failure are becoming recurrent ${ }^{[1]}$. This dire scenario is threatening food security in the developing world where a majority of the population relies on smallholder farms for their daily food needs. Changing weather patterns and recurrent extreme weather events are pushing smallholder farmers to resort to and/or intensify climate-smart practices like agroforestry ${ }^{[4]}$. Agroforestry is a land use system that has been practiced by farmers for centuries and it is well known to provide several ecosystem services that benefit farmers and other land users ${ }^{[5-10]}$. However, in recent years, farmers have been intensifying this practice in order to benefit from its diverse ecosystem services which helps them to foster climate change adaptation, enhance resilience and attenuate vulnerability ${ }^{[11-13]}$.

In Cameroon, studies have shown that agroforestry provides different social, economic and environmental benefits to agroforestry practitioners ${ }^{[5,10,14,15]}$. The diversity of services provided varies with the type of agroforestry practice which could be home gardens with livestock, home gardens without livestock, scattered trees on croplands, improved fallows, live fences/hedges and windbreaks, plantation crop-based agroforestry, apiculture-based agroforestry, and fodder banks. These different agroforestry practices and the ecosystem services they provide are helping farmers adapt to, increase resilience and reduce vulnerability to climate change. This is because the provisioning, regulating, supporting and cultural services of agroforestry helps farmers to withstand stresses and shocks induced by climate change, ensures food security through the supply of food, guards against violent winds through windbreaks, reduces soil erosion, improves underground water supply, provides shade, buffers extreme climatic conditions, and sequestrates carbon which helps to mitigate climate change.

Although agroforestry has an important role to play towards reducing climate change vulnerability, enhancing resilience and fostering adaptation, very limited empirical research has been done in Cameroon to assess these vital roles of agroforestry. This study which is based on a review of literature was therefore undertaken to: (1) identify common agroforestry practices in smallholder farming systems in Cameroon faced with climate change; (2) assess the role of agroforestry towards climate change adaptation in smallholder farming systems in Cameroon; (3) examine the role of agroforestry towards the enhancement of resilience in smallholder farming systems in Cameroon; (4) evaluate the role played by agroforestry towards attenuating vulnerability in smallholder farming systems in Cameroon; and (5) examine barriers to the practice of agroforestry faced with climate variability and change.

\section{Climate Variability and Change in Cameroon: Indicators and Impacts on Smallholder Farmers}

Climate variability and change is a reality in Cameroon evidenced by different indicators and adverse impacts on farmers in particular and agriculture in general ${ }^{[16-25]}$. Cameroon's diverse climatic, agro-ecological and relief regions have been experiencing recurrent extreme weather events in recent decades. Some of the common indicators of climate variability and change perceived by farmers have included droughts (especially in the northern parts of the country), floods (especially in the coastal regions of the country), pests and diseases, invasive plant and animal species, high temperatures, extreme sunshine, bushfires (especially in the northern regions, the western highlands and the transition zones bordering the forested southern part of the country), scanty and erratic rainfall, frequent storms, prolong dry spells, and the extension of arid lands towards the humid southern part of Cameroon. The recurrence of these extreme weather events have major repercussions on smallholder farmers who depend largely on the existence of favourable climatic conditions for cultivation. Thus, the major impacts of climate variability and change on smallholder farmers and farming systems include: crop failure, drop in crop yields, poor quality of farm products, pest and disease attacks, destruction of crops by bushfires, sickness and death of farmers, soil infertility due to rampant soil erosion and soil degradation, reduction in arable land, rain-fed agriculture increasing becoming difficult necessitating irrigation, post-harvest losses owing to poor climatic conditions and poor storage facilities, rapid spread of weeds which destroy crops, frequent blight episodes especially in crops such as tomato and potato, disease attack of livestock especially small ruminants such as goats, sheep and rabbits as well as pigs 
including local fowls and table birds. The indicators of climate variability and change and impacts on smallholder farmers in Cameroon are varied. This in essence calls for swift action towards promoting climate-smart and environmentally friendly practices like agroforestry which have stood the test of time. Agroforestry which is seemingly a new nomenclature for an old practice has been practiced for centuries by primitive communities and peasant farmers around the world. However, faced with climate variability and change, farmers are increasing intensifying the practice in order to mitigate the adverse impacts of climate variability and change while enhancing resilience, reducing vulnerability and improving adaptation.

\section{Climate Change and Common Agroforestry Practices of Smallholder Farmers}

Cameroon being a country found in the tropics, is bound to bear the brunt of current and predicted changes in climate. This is worsened by the limited adaptive capacity of the population (especially smallholder farmers) as well as high dependence on rain-fed agriculture by farmers. Thus, in the face of climate change adversities, most smallholder farmers have been modifying their smallholder farming systems by integrating and/ or intensifying the practice of agroforestry. The most common agroforestry practices of smallholder farmers in the face of climate variability and change include: home gardens with livestock, home gardens without livestock, scattered trees on croplands, improved fallows, live fences/hedges and windbreaks, coffee-based agroforestry, cocoa-based agroforestry, apiculture-based agroforestry, fodder banks, oil palm-based agroforestry, rubber-based agroforestry, banana-based agroforestry ${ }^{[26-33]}$.

Home gardens with livestock and home gardens without livestock are practiced around homesteads where tree/shrub species like plums, mangoes, guavas, bittterleaf, oranges, avocados, oil palms, coconut, Calliandra, Leucaena, and others such as cypress and Eucalyptus are integrated with crops such as plantains, cocoyams, yams, cassava, maize, beans, vegetables as well as livestock like pig, goats, sheep and poultry. Scattered trees on croplands is an agroforestry practices where trees/shrubs are dotted all over the farm plot of a farmer. These tree/shrub species are either planted by the farmer or deliberately maintained during the cultivation of the farm. Most of the tree/shrub species integrated in these farm plots are either biofertilizing species, fruit trees, fuelwood trees, trees for windbreaks, trees to control soil erosion, trees for building materials etc. Common crops integrated in the system include food crops like maize, beans, yams, cocoyams, cassava, sweet potato, potato, vegetables etc. Improved fallows are also increasingly being intensified by farmers in the face of climate change. These improved fallows are mostly made up of biofertilizing species like Tephrosia spp, Leucaena spp, Sesbania spp, Calliandra calothrysus etc. Tree-based biofertilising species like Leucaena spp and Calliandra calothrysus are integrated simultaneously with crops while shrub-based biofertilizing species like Tephrosia spp and Sesbania spp harvested and used as mulch during the cultivation of crops in order to improve soil fertility. Common crops cultivated using improved fallows include cocoyams, maize, beans, groundnuts, yams, cocoyams, cassava, and vegetables. Live fences/ hedges and windbreaks are equally used by farmers to limit the impacts of climate change. Farmers cultivating crops such as banana and plantains as well as rubber, coffee and cocoa have been noted to use live fences/ hedges and windbreaks like Eucalyptus, cypress and bamboo. Plantation crop-based agroforestry practices like coffee, banana, rubber, oil palm and cocoa are also very common. They are increasingly being intensified by farmers faced with the adversities of climate variability and change in Cameroon. These plantation crop-based agroforestry practices are increasingly integrating more biofertilizing tree/shrub species, fruit trees as well as windbreaks which make the systems more resilient to extreme climate events. Fodder banks are also increasingly being used by farmers in the face of climate variability and change. Owing to the scarcity of food to feed animals like pigs, goats, sheep, rabbits and fowls, farmers have resorted to fodder banks/cut and carry systems in order to meet the food needs of the livestock being reared.

The aforementioned agroforestry practices can be classified into three major agroforestry systems including: agrosilvicultural, silvopastoral and agrosilvopastoral systems. Agrosilvicultural agroforestry systems are systems that integrate trees/shrubs and crops. Examples of practices that fall under this system are: home gardens without livestock, scattered trees on croplands, improved fallows, plantation crop-based agroforestry practices etc. Silvopastoral systems are those that integrate trees/shrubs with livestock/pasture with the main examples being trees on pasturelands and fodder banks. Agrosilvopastoral systems are those that integrate trees/shrubs with crops as well as livestock/pasture with examples being plantation crops with livestock/pasture as well as home gardens with livestock. These different agroforestry systems and practices are increasingly being intensified by farmers all over Cameroon in a bid to mitigate the impacts of climate change, enhance resilience, reduce vulnerability and improve adaptation. 


\section{Agroforestry and Adaptation to Climate Change among Smallholder Farmers}

In Cameroon, different studies have been undertaken uncovering a plethora of adaptation options practiced by farmers in the face of climate change ${ }^{[34-39]}$, with few focusing on agroforestry. Around the world, studies have shown that agroforestry plays an important role towards enhancing farmers' adaptation to climate change ${ }^{[4,11,12,40-}$ ${ }^{45]}$. In Cameroon, studies conducted by ${ }^{[26,27,30,32,46]}$, in the western highlands - specifically in the northwest region indicated that agroforestry has a major role to play as far as adaptation to climate change is concerned. This is more so for smallholder farmers and smallholder farming systems which are highly vulnerable to climate change owing to their limited adaptive capacity. Agroforestry is an agroecological, climate-smart and environmentally friendly option. Agroforestry has the capacity to provide different ecosystem services such as provisioning, regulating, supporting and cultural which help farmers adapt in the face of climate change.

Through provisioning services such as food, water supply, fodder, fuelwood, construction materials, honey, traditional medicines, and stakes/supports for crops, agroforestry helps farmers reduce food insecurity, improve health conditions as well as diversify sources of income and livelihood which helps farmers practicing agroforestry to better adapt than their non-agroforestry practicing counterparts. Regulating services like windbreaks, erosion control, pest and disease control, carbon sequestration and micro-climate buffering help to make agroforestry systems more resilient in the face of extreme climate events which enhances farmers' adaptation to climate change. Windbreaks help to protect crops from the storms thereby increasing crop productivity. Erosion control helps to protect the top soil from being carried away which maintains the soil's fertility and improves crop yields. Pest and disease control helps to protect crops and animals from disease attacks which improves crop and animal productivity. Carbon sequestration and microclimate buffering all help to mitigate climate change and moderate the adversities of climate change which go a long way enhance smallholder farmers' and smallholder farming systems' adaptation to climate change. Supporting services of agroforestry like soil fertility improvement, improved nutrient cycling and pollination help to improve crop yields which go a long way to reduce food insecurity and enhance farmers' adaptation to climate change. Cultural services of agroforestry also play an important role in enhancing farmers' adaptation to climate change as farmers' cultural identity and spirituality are key elements ensuring adaptation in the face of climate change. In the western highlands of Cameroon, the Bamileke hedgescape ("Bocage Bamileke") is a practice that has existed for centuries among the Bamileke people of the grassfield zone of Cameroon and it is today part and parcel of their culture. This practice which constitutes an agroforestry system is playing a major role in climate change adaptation among the Bamileke people.

\section{Agroforestry for Vulnerability Attenuation and Resilience Enhancement to Climate Change among Smallholder Farmers}

Smallholder farmers in Cameroon are highly exposed to the adversities of climate variability and change; they are highly sensitive and their adaptive capacity leaves much to be desired ${ }^{[17]}$. This makes farmers and farming systems highly vulnerable to climate variability and change ${ }^{[47]}$. Smallholder farmers are exposed to extreme weather events such as droughts, floods, high temperatures, extreme sunshine, scanty and erratic rainfall, recurrent storms, prolong dryness as well as other extreme events such as bushfires, pest and diseases as well as invasive weeds. Smallholder farmers and farming systems are highly sensitive to extreme weather events due to poor/archaic farming practices and the rural setting of most of these farming systems which makes it impossible for them to quickly adopt innovative and modern practices. The adaptive capacity of farmers and farming systems is equally limited owing to limited access to livelihood assets including financial (household income, access to credit, access to bank accounts, savings, remittances, banking infrastructures), social (membership in farming groups, membership in social organizations), physical (agricultural equipment, access to infrastructures like roads, markets, internet and other ICTs), natural (land, water, fertile soils) and human (health, education, skillsets, labour). Thus, vulnerability to climate variability and change is a function of exposure, sensitivity and adaptive capacity ${ }^{[48]}$, and since smallholder farmers and smallholder farming systems in Cameroon are highly exposed, highly sensitive and have a limited adaptive capacity to climate change, they are highly vulnerable.

Resilience to climate change on its part is the ability to withstand stresses and shocks induced by climate change such as high temperatures, prolong dryness, floods, droughts, bushfires, pests and diseases etc. Most smallholder farmers and smallholder farming systems in Cameroon are not very resilient to climate change adversities ${ }^{[49-52]}$, owing to poor farming practices like monoculture and highly intensive practices involving the application of mineral fertilizers and pesticides which 
destroys soils through the annihilation of soil organisms.

Thus, agroforestry is an agroecological, climate-smart and environmentally benign practice which is capable of reducing vulnerability and enhancing smallholder farmers' resilience to climate change in Cameroon. This is through the many ecosystem services provided by agroforestry. Different agroforestry practices like home gardens with livestock, home gardens without livestock, trees/ shrubs on pasturelands, trees/shrubs on croplands, fodder banks, improved fallows, live fences/hedges, apiculturebased agroforestry practice, plantation crops with trees/ shrubs, plantation crops with livestock/pastures all contribute towards the provision of four main categories of ecosystem services i.e. provisioning, regulating, supporting and cultural. These diverse ecosystem services play a great role towards reducing vulnerability and enhancing resilience for agroforestry practicing farmers. Studies carried out in the western highlands of Cameroon by ${ }^{[26-31,33,51]}$, indicated that agroforestry has a great role to play towards enhancing resilience and reducing vulnerability to climate variability and change in smallholder farming systems.

Supporting services of agroforestry such as improved nutrient cycling, soil fertility improvement, and pollination help to improve crop yields which go a long way to reduce food insecurity, attenuate vulnerability and improve farmers' resilience to climate change. Cultural services of agroforestry also play an important role in enhancing farmers' resilience and attenuating vulnerability to climate change as farmers' cultural identity and spirituality are key elements that can improve resilience and attenuate vulnerability to climate change. Farmers' cultural identity and spirituality is closely tied to their indigenous knowledge which is a major driver towards improving resilience and attenuating vulnerability. For example in the grassfields of Cameroon, the Bamileke hedgescape ("Bocage Bamileke") is an agroforestry practice which has been there for centuries and counting and is a product of the ingenuity of the Bamileke people. These hedgescapes today play a very important role towards improving the resilience and attenuating vulnerability of smallholder farmers as it contributes towards the provision of a plethora of ecosystem services to the Bamileke indigenes. Provisioning services such as food, water supply, fodder, fuelwood, construction materials, honey, traditional medicines, and stakes/supports for crops, agroforestry helps farmers reduce food insecurity, improve health conditions as well as diversify sources of income and livelihood which reduces vulnerability and improves resilience for agroforestry practicing farmers when compared to non-agroforestry practicing farmers.
Regulating services like windbreaks, erosion control, pest and disease control, carbon sequestration and microclimate buffering help to make agroforestry systems more resilient in the face of extreme climate events which enhances farmers' resilience and reduces vulnerability to climate change. Windbreaks help to protect crops from the storms thereby increasing crop productivity. Erosion control helps to protect the top soil from being carried away which maintains the soil's fertility and improves crop yields. Pest and disease control helps to protect crops and animals from disease attacks which improves crop and animal productivity. Carbon sequestration and microclimate buffering all help to mitigate climate change and moderate the adversities of climate change. All these regulating services of agroforestry help to enhance smallholder farmers' and smallholder farming systems' resilience while reducing vulnerability to climate change.

\section{Barriers to the Practice of Agroforestry in the Face of Climate Change}

Although smallholder farmers in Cameroon are increasingly resorting to and/or intensifying agroforestry practices in the face of climate variability and change, most are faced with a series of barriers including prohibitive land tenure practices, prohibitive tree tenure, gender bias in land/tree ownership, inadequate information, inadequate support/incentives, limited extension services, limited knowledge of climate change, recurrent nature of extreme weather events, poor legal and policy framework governing the practice of agroforestry. Land tenure systems are different parts of Cameroon are very prohibitive which makes it difficult for farmers to practice agroforestry. Mostly indigenes and males have the right to own land in rural areas in Cameroon which makes it very difficult for non-indigenes and females to practice agroforestry as land is an indispensable asset for the practice of agroforestry. Tree tenure practices are also prohibitive as state and customary laws are not in agreement with respect to ownership rights of trees found on croplands for example. Equally, most customary laws prohibit non-indigenes from owning trees which discourages the practice of agroforestry. Gender bias in land and tree ownership equally discourages some farmers from practicing agroforestry. The female folk in particular have very limited access to land and trees especially in rural areas in Cameroon where patriarchy is deeply rooted. Inadequate information and support/incentives to farmers discourage farmers from practicing agroforestry as most farmers are unaware of the best agroforestry practices to adopt in the face of climate change which is further compounded by the lack of support/incentives. 
Limited extension services and limited knowledge of climate change are also major barriers to the adoption of agroforestry in the face of climate change. Extension services help to disseminate information and their absence makes farmers unaware of best agroforestry practices as well as climate change trends. Recurrent extreme weather events have made it very difficult for farmers to adjust their agroforestry practices to match the changing trends. There is no policy and legal framework in Cameroon which governs the agroforestry sector. This has made it very difficult to distinguish between trees that are part of the forest domain and those that are of the agricultural domain. Until this is made clear, those willing to practice agroforestry will continue to be discouraged.

\section{Conclusions and Perspectives}

Agroforestry is a climate-smart, agroecological and environmentally benign practice with a major role to play towards enhancing resilience, fostering adaptation and reducing vulnerability to the adverse effects of climate variability and change. The different ecosystem services of agroforestry notably provisioning, regulating, supporting and cultural services have been found to enhance food security, diversify sources of income and livelihood, supply medicinal products, guard against pests and diseases, provide protection from wind and soil erosion and mitigate the adverse effects of climate change. This goes to show that agroforestry practicing farmers are in a better position in terms of climate change adaptation, resilience, and vulnerability attenuation owing to the diversity of ecosystem services they derive from their agroforestry practices which nonagroforestry practicing farmers are unable to procure. Although agroforestry has been found to play a major role in climate change adaptation, resilience enhancement and vulnerability attenuation, most of the empirical research has been carried out in the western highlands specifically the north-west region of Cameroon. More indepth empirical research needs to be conducted in the other four agroecological zones of Cameroon showing the role agroforestry systems/practices could play towards fostering climate change adaptation, enhancing resilience and attenuating vulnerability.

\section{Acknowledgement}

I wish to sincerely thank the "African Food Security and Climate Army (AFSACA)" - a Non-Governmental Organization (NGO) based in Dschang, west region of Cameroon, for providing financial and material support that led to the completion of this study.

\section{References}

[1] FAO, IFAD, UNICEF, WFP, WHO, 2018. The State of Food Security and Nutrition in the World 2018. Building climate resilience for food security and nutrition. Rome, FAO. Licence: CC BY-NC-SA 3.0 IGO.

[2] International Fund for Agricultural Development (IFAD), 2012. Sustainable smallholder agriculture: feeding the world, protecting the planet. Proceedings of the Governing Council Events. In conjunction with the thirty-fifth session of IFAD's Governing Council, February 2012. https://www.ifad. org/documents/10180/6d13a7a0-8c57-42ec-9b01856f0e994054 pdf.

[3] Intergovernmental Panel on Climate Change (IPCC), 2007. Climate Change 2007: Impacts, Adaptation and Vulnerability. Summary for Policymakers, IPCC AR4 WGII, Cambridge University Press, Cambridge, UK. https://www.ipcc.ch/pdf/assessment-report/ar4/ wg2/ar4-wg2-spm. pdf.

[4] Awazi, N.P., Tchamba, N.M., 2019. Enhancing agricultural sustainability and productivity under changing climate conditions through improved agroforestry practices in smallholder farming systems in sub-Saharan Africa. Afr. J. Agric Res. 14(7), 379-388.

[5] Molua, E.L., 2005. The economics of tropical agroforestry systems: the case of agroforestry farms in Cameroon. Forest Policy and Economics. 7(2), 199221.

[6] Jose, S., 2009. Agroforestry for ecosystem services and environmental benefits: an overview. Agrofor Syst. 76, 1-10.

[7] Asaah, E.K., Tchoundjeu, Z., Leakey, R.R.B., Takousting, B., Njong, J., Edang, I., 2011. Trees, agroforestry and multifunctional agriculture in Cameroon. Int J Agric Sustain. 9(1), 110-119.

[8] Leakey, R.R.B., 2017. Socially Modified Organisms in Multifunctional Agriculture addressing the needs of Smallholder Farmers in Africa. Arch Crop Sci. $1(1), 20-29$.

[9] Leakey, R.R.B., 2019. A holistic approach to sustainable agriculture: trees, science and global society. In: Mosquera-Losada, M.R. and Prabhu, R. (eds.), Agroforestry for sustainable agriculture, Burleigh Dodds Science Publishing, Cambridge, UK. ISBN: 9781 78676220 7; www.bdspublishing.com.

[10] Awazi, N.P., Avana, T.M.L., 2020. Agroforestry as a sustainable means to farmer-grazier conflict mitigation in Cameroon. Agroforestry Systems. 94(6), 2147-2165. 
DOI: https://doi.org/10.1007/s10457-020-00537-y (0123456789

[11] Mbow, C., Smith, P., Skole, D., Duguma, L., Bustamante, M., 2013a. Achieving mitigation and adaptation to climate change through sustainable agroforestry practices in Africa. Current Opinion in Environmental Sustainability. 6, 8-14.

[12] Mbow, C., Noordwijk, M.V., Luedeling, E., Neufeldt, H., Minang, P.A., Kowero, G., 2013b. Agroforestry solutions to address food security and climate change challenges in Africa. Current Opinion in Environmental Sustainability. 6, 61-67.

[13] Amare, D., Wondie, M., Mekuria, W., Darr, D., 2018. Agroforestry of smallholder farmers in Ethiopia: practices and benefits. Small Scale For. 18(1), 39-56.

[14] Shidiki, A.A., Ambebe, T.F., Awazi, N.P., 2020. Agroforestry for Sustainable Agriculture in the Western Highlands of Cameroon. Haya: The Saudi Journal of Life Sciences. 5(9), 160-164.

[15] Tsufac, A.R., Awazi, N.P., Yerima, B.P.K., 2021. Characterization of agroforestry systems and their effectiveness in soil fertility enhancement in the South West region of Cameroon. Current Research in Environmental Sustainability. 3, 100024.

DOI: http://dx.doi.org/10.1016/j.crsust.2020.100024

[16] Fongnzossie, F.E., Sonwa, D.J., Kemeuze, V., Mengelt, C., 2018. Assessing climate change vulnerability and local adaptation strategies in adjacent communities of the Kribi-Campo coastal ecosystems. South Cameroon. Urban Climate. 24, 1037-1051.

[17] Molua, E., Lambi, C., 2002. Climate variability, vulnerability and effectiveness of farm-level adaptation options: the challenges and implications for food security in Southwestern Cameroon, Environment and Development Economics. Cambridge University Press. 7, 529-545. http://nersp.nerdc.ufl.edu/ vecy/ LitSurvey/Molua.pdf

[18] Molua, E.L., 2006. Climate trends in Cameroon: implications for agricultural management. Climate Res. 30, 255-262.

[19] Molua, E.L., 2008. Turning up the heat on African agriculture: The impact of climate change on Cameroon's agriculture. AfJARE Vol 2, No 1.20 p. http:// ageconsearch.umn.edu/bitstream/56967/2/0201\%20 si $\% 20$ malua $\% 20-\% 2026 \% 20$ may.pdf.

[20] Sunjo, E.T., Kometa, S.S., Amawa, S.G., 2012. The Implications of Rainfall Variability on Cattle and Milk Production in Jakiri Sub-Division, North West Region, Cameroon. Journal of Agricultural Science. 4(10). http://www.ccsenet.org/journal/index.php/jas/ article/view/16241/13518
[21] Gur, A.S., Kimengsi, J.N., Sunjo, T.E., Awambeng, A.E., 2015. The Implications of Climate Variability on Market Gardening in Santa Sub-Division, NorthWest Region of Cameroon. Environment and Natural Resources Research. 5(2), 14-23.

[22] Innocent, N.M., Bitondo, D., Azibo, B.R., 2016. Climate variability and change in the Bamenda Highlands of The North-West Region of Cameroon: Perceptions, Impacts and Coping mechanisms. British Journal of Applied Sciences and Technology. 12(5), $1-18$.

[23] Ngala, I.K., Kongnso, M.E., Kwei, J., 2020a. Mountain Apiculture and Environmental Dynamics: Impact of Climate Variability on Bee Farming in Oku, Cameroon. International Journal of Environmental, Sustainability, and Social Science. 1(3), 01-11.

DOI: https://doi.org/10.38142/ijesss.v1i3.33

[24] Ngala, K.I., Nyanchi, G.T., Kongnso, M.E., Antu, N.V., Nghobuoche, F., Muala, M.N., 2020b. Climate Variability Impact and Adaptation: The Experience of Maize Farmers in Bui Division, Northwest Cameroon. International Journal of Environment, Agriculture and Biotechnology. 5(3), 683-698.

[25] Kongnso, M.E., Buba, U.H., Nfor, J.T., 2021. Implications of Climatic Stressors on Agro-Pastoral Resources Among Mbororo Communities Along the Slopes of Kilum-Ijim Mountain, North West Region, Cameroon. Front. Sustain. Food Syst. 5, 685071. DOI: https://doi.org/10.3389/fsufs.2021.685071

[26] Awazi, N.P., 2018. Adaptation Options Enhancing Farmers' Resilience to Climate Change. LAP LAMBERT Academic Publishing. pp. 132. ISBN-10: 3330027940; ISBN-13: 978-3330027947.

[27] Awazi, N.P., Tchamba, N.M., Tabi, F.O., 2019a. An assessment of adaptation options enhancing smallholder farmers' resilience to climate variability and change: Case of Mbengwi Central sub-Division, North-West Region of Cameroon. Afr. J. Agric. Res. 14(6), 321-334.

[28] Awazi, N.P., Tchamba, N.M., Avana, T.M.L., 2019b. Climate change resiliency choices of small-scale farmers in Cameroon: determinants and policy implications. Journal of Environmental Management. 250, 109560.

DOI: https://doi.org/10.1016/j.jenvman.2019.109560

[29] Awazi, N.P., Tchamba, N.M., Temgoua, L.F., 2020a. Enhancement of resilience to climate variability and change through agroforestry practices in smallholder farming systems in Cameroon. Agroforestry Systems. 94(3), 687-705.

DOI: https://doi.org/10.1007/s10457-019-00435-y 
[30] Awazi, N.P., Tchamba, N.M., Temgoua, L.F., 2020 b. Climate-smart practices of smallholder farmers in Cameroon faced with climate variability and change: The example of agroforestry. Agricultural Research. 10(1), 83-96.

DOI: https://doi.org/10.1007/s40003-020-00477-0.

[31] Awazi, N.P., Quandt, A., 2021. Livelihood resilience to environmental changes in areas of Kenya and Cameroon: a comparative analysis. Climatic Change. 165,33 .

DOI: https://doi.org/10.1007/s10584-021-03073-5

[32] Awazi, N.P., Tchamba, N.M., Temgoua, L.F., Avana, T.M.L., 2021b. Agroforestry as an adaptation option to climate change in Cameroon: assessing farmers' preferences. Agricultural Research.

DOI: https://doi.org/10.1007/s40003-021-00562-y

[33] Awazi, N.P., Tchamba, M.N., Temgoua, L.F., Avana, T.M.L., Shidiki, A.A., Forje, G.W., Nfornkah, B.N., 2021c. Climate-Smart and Agro-ecological Farming Systems of Smallholder Farmers. In: Galanakis CM (ed) Environment and Climate-smart Food Production. Springer Nature Switzerland AG.

DOI: https://doi.org/10.1007/978-3-030-71571-7_2.

[34] Kimengsi, J.N., Azibo, B.R., 2015. Building an indigenous agro-pastoral adaptation framework to climate change in Sub-Saharan Africa: experiences from the North-West Region of Cameroon. Procedia Environmental Sciences. 29, 126-127.

[35] Azibo, B.R., Kimengsi, J.N., Buchenrieder, G., 2016. Understanding and Building on Indigenous Agro-Pastoral Adaptation strategies for Climate Change in Sub-Saharan Africa: Experiences from Rural Cameroon. Journal of Advances in Agriculture. 6(1), 833-840.

[36] Azong, M., Kelso, C.J., Naidoo, K., 2018. Vulnerability and resilience of female farmers in Oku, Cameroon, to Climate Change. African Sociological review. 22(1), 31-53.

[37] Bate, B.G., Kimengsi, J.N., Amawa, S.G., 2019. Determinants and policy implications of farmers' climate adaptation choices in rural Cameroon. Sustainability. 11, 1921.

DOI: https://doi.org/10.3390/su11071921.

[38] Tume, S.J.P., Kimengsi, J.N., Fogwe, Z.N., 2019. Indigenous knowledge and farmer perceptions of climate and ecological changes in the Bamenda Highlands of Cameroon: Insights from the Bui Plateau. Climate. 7, 138.

DOI: https://doi.org/10.3390/cli7120138

[39] Tume, S.J.P., Kimengsi, J.N., 2021. Indigenous and modern agro-based climate adaptation practices in rural Cameroon. International Journal of Environmental Studies.

DOI: https://doi.org/10.1080/00207233.2021.1977538

[40] Lin, B.B., 2007. Agroforestry management as an adaptive strategy against potential microclimate extremes in coffee agriculture. Agricultural and Forest Meteorology. 144, 85-94.

[41] Nguyen, Q., Hoang, M.H., Öborn, I., van Noordwijk, M., 2013. Multipurpose agroforestry as a climate change resiliency option for farmers: an example of local adaptation in Vietnam. Climatic Change. 117, 241-257.

[42] Newaj, R., Chavan, S.B., Prasad, R., 2015. Climate-smart agriculture with special reference to agroforestry. Indian J. of Agroforestry. 17(1), 96-108.

[43] Newaj, R., Chaturvedi, O.P., Handa, A.K., 2016. Recent development in agroforestry research and its role in climate change adaptation and mitigation. Indian Journal of Agroforestry. 18(1), 1-9.

[44] Quandt, A., Neufeldt, H., McCabe, J.T., 2017. The role of agroforestry in building livelihood resilience to floods and droughts in semi-arid Kenya. Ecol Soc. 22(3).

[45] Quandt, A., Neufeldt, H., McCabe, J.T., 2018. Building livelihood resilience: what role does agroforestry play? Clim Dev.

DOI: https://doi.org/10.1080/17565529.2018.1447903.

[46] Awazi, N.P., Tchamba, N.M., 2018. Determinants of small-scale farmers' adaptation decision to climate variability and change in the North-West Region of Cameroon. Afr. J. Agric. Res. 13(12), 534-543.

[47] Awazi, N.P., Tchamba, N.M., Temgoua, L.F., Avana, T.M.L., 2020c. Appraisal of smallholder farmers' vulnerability to climatic variations and changes in Cameroon. Scientific African. 10, e00637. DOI: https://doi.org/10.1016/j.sciaf.2020.e00637

[48] Gbetibouo, G.A., Ringler, C., 2009. Mapping South African Farming Sector Vulnerability to Climate Change and Variability; A Sub national Assessment. IFPRI Discussion Paper 00885.

[49] Awazi, N.P., Temgoua, L.F., Shidiki, A.A., 2021a. Examining farmers' resilience to climate change and policy ramifications in North-West Cameroon. Current World Environment. 16(1), 46-60.

DOI: http://dx.doi.org/10.12944/CWE.16.1.06

[50] Awazi, N.P., Quandt, A., Kimengsi, J.N., 2021d. Endogenous drivers of livelihood resilience in the Western Highlands of Cameroon: Implications for local adaptation policy and practice for long-term non-migration. Conference: GOBESHONA Global Conference on Locally-led climate adaptation approaches 
and their role for environmental non-migration in the Global South.

[51] Awazi, N.P., July, 2020. Vulnerability attenuation and resilience enhancement to climate variability and change through agroforestry practices in smallholder farming systems in the north-west region of Cameroon. Ph.D. Thesis, The University of Dschang, Cameroon; Unpublished.
[52] Awazi, N.P., Tchamba, M.N., Temgoua, L.F., Avana, T.M.L., 2020d. Farmers' adaptive capacity to climate change in Africa: Small-scale farmers in Cameroon. In: Leal Filho W., Ogugu N., Adelake L., Ayal D., da Silva I. (eds) African Handbook of Climate Change Adaptation. Springer, Cham.

DOI: https://doi.org/10.1007/978-3-030-42091-8_9-1 